\title{
PALAVRAS DE ABERTURA DO IV ENCONTRO
}

\author{
pela Prof: Dra. Cecilia Maria Westphalen, diretora do Setor de \\ Clências Humanas, Letras e Artes da \\ Universidade Federal do Paraná
}

\section{Senhoras, Senhores:}

Sejam as minhas palavras a expressão do júbilo com que a Unlversidade Federal do Paraná hospeda o IV Encontro Nacional de Professores de Literatura Portuguesa, agradecendo a todos a sua índicação no Encontro do Recife, e, neste momento, a presença dos que acorreram à sua convocação e vieram a Curitiba.

No Paraná, onde as estruturas demográficas são profundamente marcadas pela contribuição de imigrantes de variadas etnias, paradoxalmente, entretanto, temos extraordinária consciência do substrato lusitano em nossa formação.

Assim, na Universidade, procuramos estudar e compreender as instituiçōes portuguesas de permanência no Brasil, seja na organizaçāo da familia, nos costumes populares, na erudição acadêmica, mas, sobretudo, nesta flor extraordinária da comunicação que é a língua portuguesa.

Eis por que é para nós muito significativo o estudo da Literatura Portuguesa, a fonte realimentadora do idioma que falamos.

Neste sentido, é mesmo muito importante para todo o Brasil e todos os bıasileiros o maior e melhor conhecimento da Literatura Portuguesa, sua difusão, sejam os clássicos das caravelas, sejam aqueles dos nossos dias.

E pela Literatura Portuguesa, realimentando a língua portuguesa falada no Brasil, é que manteremos estes laços culturais intrínsecos que nos unem a Portugal, e que são próprios da nossa comum personalidade.

Não só por razōes históricas, mas também pelos interesses comuns de nossos países no mundo contemporâneo, devem ser fortalecidos os laços de solidariedade entre o povo português e o brasileiro. 
Aquele já deu provas da sua universalidade, do imenso que é capaz de construir sendo a alma grande. Este, emergindo como potêncla. Ambos, juntos, capazes de grande futuro no destino da civilização ocidental.

Ainda uma vez, a Universidade Federal do Paraná, pelo Setor de Clências Humanas, Letras e Artes, agradece o apoio recebido para a realizaçăo deste Encontro, do Exmo. Sr. Ministro da Educação e Cultura, do Instituto Português de Alta Cultura, $E$ de outras entidades educacionais e de cultura.

Agradece, sobretudo, a presença e participação dos Senhores Professores. 